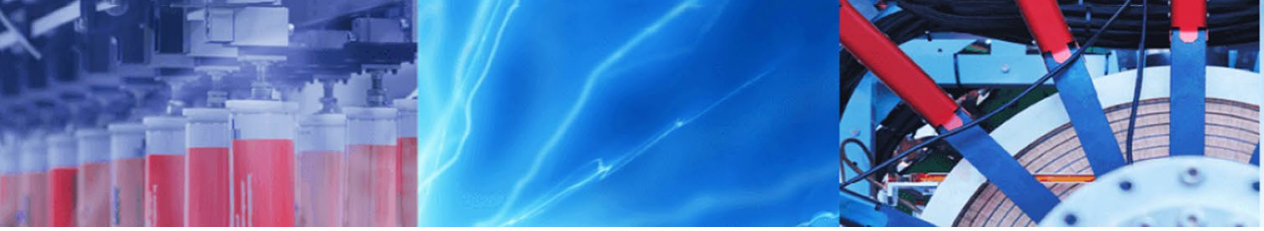

Research Article

\title{
Characterisation and mix specification of commonly used masonry mortars
}

\author{
Julian Thamboo' ${ }^{1}$. Navodi Jayarathne ${ }^{1} \cdot$ Amith Bandara $^{2}$
}

(c) Springer Nature Switzerland AG 2019

\begin{abstract}
The proper selection and execution of mortar are imperative processes in the masonry construction. While there are different mortar designations available in standards; except their compressive strengths, the detail characteristics are seldom stated. The standards mainly outline mortar mix in volume proportion without any specification on consistency limits and water to cement ratio $(\mathrm{w} / \mathrm{c})$. This leads to inconsistency in mortar mix preparation and properties in real practice. Thus an extensive experimental investigation was carried out to identify suitable consistency and $\mathrm{w} / \mathrm{c}$ limits of five commonly used masonry mortars to detail the mortar mix specification. The research was divided into three phases. The properties of mortar constitutive materials were characterised in the first phase of the research. In the second phase, the fresh properties such as bulk density, air content, and consistency were measured for those mortars with possible two different $\mathrm{w} / \mathrm{c}$ ratios. Then dry density, water absorption, sorptivity, porosity, compressive strength, flexural strength and shrinkage were determined for hardened mortars. Further the mortars were casted in non-absorbent and absorbent moulds to compare the influence of casting conditions on the hardened properties. Thereafter the third phase of experimental testing was carried out to determine the suitable consistency and $\mathrm{w} / \mathrm{c}$ ratio thresholds for those masonry mortars. Finally from the results, detail specification of those masonry mortars in terms of $\mathrm{w} / \mathrm{c}$, consistency and target compressive strength is recommended.
\end{abstract}

Keywords Masonry · Cement mortar · Cement-lime mortar · Compressive strength · Consistency $\cdot$ Water cement ratio

\section{Introduction}

Mortar is an important constitutive material in masonry construction. The prime role of masonry mortar is to provide bonding between units, distribute the stresses between unit layers and to offer thermal and sound insulation. Therefore characteristics of mortar in masonry joints are different to general purpose mortar preparations/ application. Also the performance of masonry is greatly influenced by strength and durability characteristics of mortar. The erosion or deterioration of the mortar would reduce the load carrying capacity, specially the in-plane and out of plane resistance of masonry. Nowadays cement mortars are commonly used in modern masonry construction. However lime or lime-cement mortars have been widely used in historic buildings.

The masonry design standards generally specify the mortar as according to the volume mix proportions. Some of the specifications of cement and cement-lime mortars stated in different masonry standards are given in Table 1. BS EN 1996-1-1 [1] designates the mortar as according to their compressive strength expressed as the letter $\mathrm{M}$ followed by the compressive strength in MPa. AS 3700 [2] specifies masonry mortars with the term starts " $M$ " followed by numbers 1-4. Further the CSA S304.104 [3] directs to use four types of mortars namely S, N, O

$\triangle$ Julian Thamboo, jathamboo@seu.ac.lk; Navodi Jayarathne, nvdjayarathne1@gmail.com; Amith Bandara, amith.bandara@icc-construct.com | 'Department of Civil Engineering, South Eastern University of Sri Lanka, Oluvil 32360, Sri Lanka. ${ }^{2}$ International Construction Consortium (Pvt) Ltd, Nugegoda, Sri Lanka.

SN Applied Sciences (2019) 1:292 | https://doi.org/10.1007/s42452-019-0312-z 
Table 1 Summary of mortar classifications in different masonry design standards

\begin{tabular}{lllll}
\hline Standard & $\begin{array}{l}\text { Mortar } \\
\text { classifica- } \\
\text { tion }\end{array}$ & \multicolumn{2}{l}{ Volume proportion } \\
\cline { 3 - 5 } & Cement & Lime & Sand \\
\hline BS EN 1996-1-1 [1] & M12 & 1 & 0 to 0.25 & 3 \\
& M6 & 1 & 0 to 0.5 & 3 to 4.5 \\
& M4 & 1 & 0 to 1 & 5 to 6 \\
AS 3700 [2] & M2 & 1 & 0 to 2 & 7 to 9 \\
& M1 & 1 & 1 & 3 \\
& M2 & 1 & 2 & 9 \\
CSA S304.1-04 [3] & M3 & 1 & 1 & 4 to 6 \\
& $\mathrm{~S} 4$ & 1 & 0 to 0.5 & 3 to 4.5 \\
& $\mathrm{~N}$ & 1 & 0 & 3 \\
& $\mathrm{O}$ & 1 & 1 & 6 \\
MSJC [5] & $\mathrm{K}$ & 1 & 2 & 9 \\
& $\mathrm{M}$ & 1 & 3 & 12 \\
& $\mathrm{~S}$ & 1 & 0 & 2.25 to 3 \\
& $\mathrm{N}$ & 1 & 0.25 to 0.5 & 2.25 to 3 \\
& $\mathrm{O}$ & 1 & 1.25 to 2.5 & 2.25 to 3 \\
\hline
\end{tabular}

and $\mathrm{K}$ (The letter designations do not have any technical inferences) for masonry construction and their specifications are outlined in CSA a179-04 [4]. Mortar specification of American standard MSJC [5] is given in ASTM C270 [6]. However both CSA a179-04 [4] and ASTM C270 [6] standards outline two types of mortar specifications; they are based on (1) Proportions and (2) Properties for design and construction.

Unlike concrete mix design, the masonry mortar mix is specified in bulk volumes in proportions of cement, lime and sand with no specification of water quantity and consistency limits. However the water to cement ratio $(\mathrm{w} / \mathrm{c})$ is an important parameter for cement based mixes and as emphasized more on concrete and overlooked in masonry mortars. Several studies have been carried out to determine the effects of $\mathrm{w} / \mathrm{c}$ ratios on cement mortar [7-10]. It has been reported that the increase in $\mathrm{w} / \mathrm{c}$ ratio reduces the strength properties of mortars. Also lower $\mathrm{w} / \mathrm{c}$ ratio $(<0.6)$ in masonry mortar is not possible without any admixtures due to the high finer content $[11,12]$. Subsequently $\mathrm{w} / \mathrm{c}$ ratio of mortars cannot be reduced as it influence the consistency and thereby bond development between masonry units and mortars [13-15].

Similar to concrete rheology the consistency of mortars is mainly affected by the fineness of the ingredients and $\mathrm{w} / \mathrm{c}$ ratio of the mix. Hence increase in fineness of aggregate increases the water demand to meet the specified consistency. Thus the water retentively in mortar rises with the increase of fineness modulus of aggregates [16-18]. Therefore the aggregate size of the mortar mix for masonry is mostly limited to $2.36 \mathrm{~mm}$ in standards $[19,20]$. Further the shrinkage of mortar is another important property to be concerned in masonry. The $\mathrm{w} / \mathrm{c}$ ratio and casting conditions play a significant role in shrinkage characteristics of cementitious materials [21, 22]. Hence the complete characterisation of masonry cement and cement-lime mortars on other mechanical and durability properties are not well documented in the literature. However these parameters are essential as they determine the overall performance of masonry. As the erosion or cracking of mortar in masonry would effectively reduce the bedding area between unit and mortar, thereby it would reduce the effective stress transfer in masonry under various stress states.

Nevertheless the comprehensive studies on fresh and hardened properties relevant to common types of mortar for masonry application are scarce. Also the masonry mortar is casted over absorbent material like bricks or blocks, therefore the actual effects of $\mathrm{w} / \mathrm{c}$ ratio on mortar strength and durability characteristics on absorbent condition is not well reported in literature. The previous research studies mainly used the non-absorbent moulds to examine the mortar characteristics. Therefore, this research has also undertaken an experimental investigation to examine whether or not any significant difference exist between the mortar properties determined between these two different casting methods and if difference exists, to determine distinct correlation between the two test methods.

Therefore, it is commonly observed that except the compressive strength, the other characteristics of masonry mortars are generally not well specified in the literature. Hence the objective of this research was to evaluate the suitable limits of consistency and w/c ratio for commonly used masonry mortars. For that purpose, five different cement and cement-lime mortar proportions were selected in this research. Initially the mortar constitutive materials were characterised. Thereafter fresh mortar properties of bulk density, air content and consistency were investigated for those mortar mixes. Furthermore the compressive strength, flexural strength, dry density, water absorption, sorptivity, porosity and shrinkage were examined for hardened mortar. Additionally the hardened mortar characteristics were examined with non-absorbent and absorbent conditions to further compare the effect of casting condition on mortar properties in this research. Finally from the test results of fresh and hardened property tests, further testing were carried out to determine the suitable consistency and $\mathrm{w} / \mathrm{c}$ ratio limits for masonry mortar in this research. 


\section{Materials and experimental programme}

\subsection{Material characterisation}

Ordinary Portland cement (OPC), river sand, natural hydraulic lime $(\mathrm{NHL})$ and water were the constitutive materials used for mortar mixing. OPC used in this research was classified as CEM I $42.5 \mathrm{~N}$ of BS EN 197-1 [23]. The specific gravity, fineness and specific surface of the OPC are $3.15,13 \%$ and $350 \mathrm{~m}^{2} / \mathrm{kg}$ respectively. Further the initial setting time of 160 min was obtained for the OPC through Vicat needle testing as per ASTM C191 - 18a [24]. NHL available in the local commercial market was used in this research for cement-lime mortar mixes. The specific gravity and fineness of the NHL are 2.1 and $550 \mathrm{~m}^{2} / \mathrm{kg}$. The characterisation of masonry mortars depends on the characterisation of the constitutive materials used. Therefore Table 2 presents the chemical compositions of OPC and NHL from X-ray fluorescence (XRF) analysis. Also the particle size distributions analysis of both OPC and NHL were carried out using laser diffraction method as according to ISO 13320-1 and given in Fig. 1 . It can be seen that the average particle size $\left(D_{50}\right)$ of OPC and NHL were around $17 \mu \mathrm{m}$ and $55 \mu \mathrm{m}$ respectively. Therefore overall the used NHL is slightly coarser than the OPC.

The specific gravity of river sand used in the research was 2.72. Gradation of selected river sand is shown in Fig. 2. The maximum particle size of $2.36 \mathrm{~mm}$ was maintained for mortar preparation and the fineness modulus of the sand was determined as 2.3. It means the average size of river sand particle was in between $1.18 \mathrm{~mm}$ to $0.85 \mathrm{~mm}$. ASTM C $144-17$ [20] specified limits of fine aggregate gradation to be used in masonry mortar is presented as lower and upper ranges in Fig. 2. Therefore, it could be said that the gradation of the selected

Table 2 Chemical composition of OPC and NHL

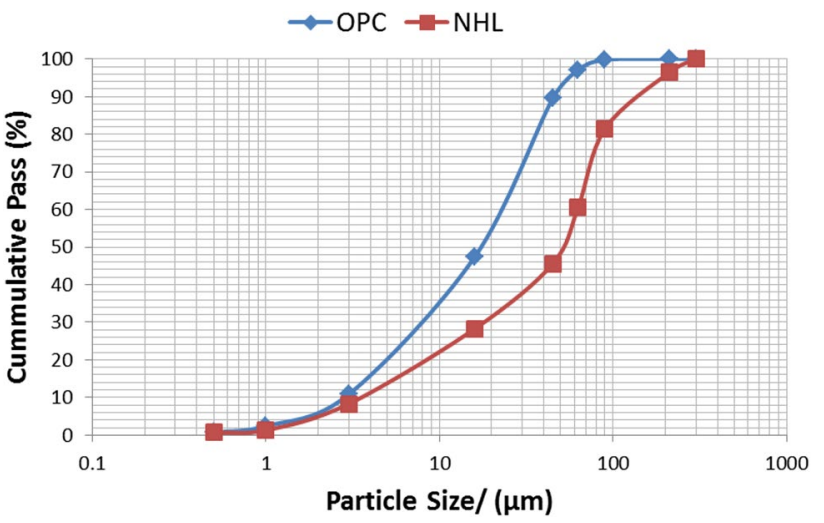

Fig. 1 Gradation of selected OPC and NHL

sand was continuous and within the range proposed for masonry mortars.

\subsection{Mortar mix proportions}

Totally five different and widely used mortar mix proportions were purposely selected from the masonry design standards to investigate in this research. Table 3 gives the selected mortar mix proportions. All the mixes were made by volume proportions as normally specified in masonry design standards; however the mass proportions were also recorded and given in Table 3 for verification.

Mortar mixing, moulding and compaction were carried out as according to the BS EN 998-2 [19]. No admixtures were added during the mixing to investigate the raw mortar characteristics in this research. Cement, lime and sand were initially mixed and then the water was added in the mix to prepare mortar. Thereafter the mortars were mixed about five minutes prior to the preparation of samples. In order to investigate the effect of $\mathrm{w} / \mathrm{c}$ ratio on the fresh and hardened characteristics, mainly two series of mortar proportions ( $A$ and $B$ ) as given in Table 3 were casted and

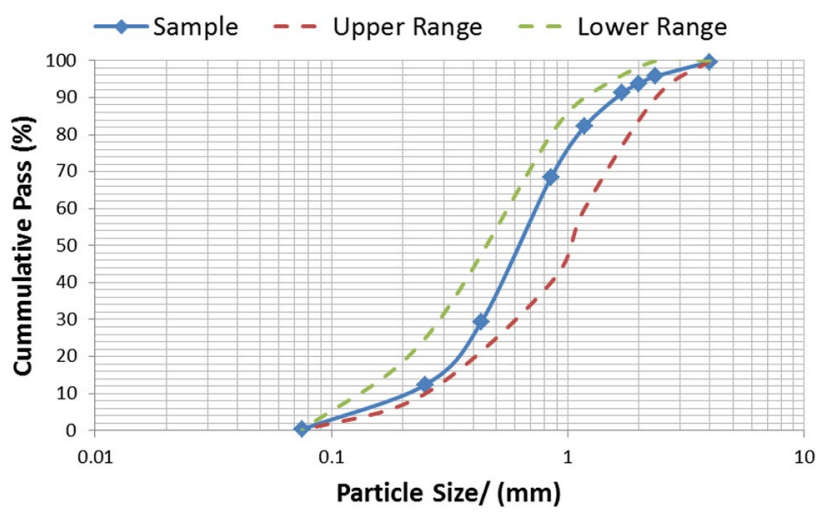

Fig. 2 Gradation of selected sand for mortar mix

\begin{tabular}{lcl}
\hline $\begin{array}{l}\text { Chemical } \\
\text { compound }\end{array}$ & $\mathrm{OPC}$ & $\mathrm{NHL}$ \\
\hline $\mathrm{CaO}$ & 63.9 & 60.3 \\
$\mathrm{SiO}_{2}$ & 19.9 & 6.2 \\
$\mathrm{Al}_{2} \mathrm{O}_{3}$ & 4.9 & 1.9 \\
$\mathrm{Fe}_{2} \mathrm{O}_{3}$ & 3.2 & 1.1 \\
$\mathrm{MgO}$ & 0.9 & 1.2 \\
$\mathrm{SO}_{3}$ & 2.4 & 1.4 \\
$\mathrm{~K}_{2} \mathrm{O}$ & 0.1 & 0.4 \\
$\mathrm{Na}_{2} \mathrm{O}$ & 0.2 & 0.1 \\
$\mathrm{Cl}$ & 0.03 & - \\
$\mathrm{LOI}$ & 4.5 & 27.4 \\
\hline
\end{tabular}


Table 3 Mortar mix proportion

\begin{tabular}{|c|c|c|c|c|c|c|c|}
\hline \multirow[t]{2}{*}{ Mortar mix } & \multicolumn{3}{|c|}{ Volume proportions } & \multicolumn{3}{|c|}{ Mass per $\mathrm{m}^{3}$ mix $(\mathrm{kg})$} & \multirow{2}{*}{$\begin{array}{l}\text { Water/ } \\
\text { cement } \\
\text { Ratio }(\mathrm{w} / \mathrm{c})\end{array}$} \\
\hline & Cement & Lime & Sand & Cement & Lime & Sand & \\
\hline A1 & 1 & 0 & 3 & 464 & 0 & 1128 & 1.0 \\
\hline A2 & 1 & 0 & 5 & 338 & 0 & 1226 & \\
\hline A3 & 1 & 0 & 8 & 172 & 0 & 1365 & \\
\hline A4 & 1 & 0.5 & 4 & 369 & 118 & 1162 & \\
\hline A5 & 1 & 1 & 6 & 169 & 92 & 1321 & \\
\hline B1 & 1 & 0 & 3 & 464 & 0 & 1128 & 0.8 \\
\hline B2 & 1 & 0 & 5 & 338 & 0 & 1226 & \\
\hline B3 & 1 & 0 & 8 & 172 & 0 & 1365 & \\
\hline B4 & 1 & 0.5 & 4 & 369 & 118 & 1112 & \\
\hline B5 & 1 & 1 & 6 & 169 & 92 & 1321 & \\
\hline
\end{tabular}

tested in this study. The $\mathrm{w} / \mathrm{c}$ ratios of series $A$ and $B$ were 1.0 and 0.8 respectively. Since it was decided not to use any admixtures in this research, the lower $\mathrm{w} / \mathrm{c}$ ratios $(<0.6)$ were not possible due the higher finer content in mortar mixes $[9,25]$.

\subsection{Tests for fresh mortar properties}

The fresh mortar characteristics were investigated through measuring wet bulk density, air content and consistency. The methodologies followed to determine the fresh mortar properties are briefly explained below. Three sets of samples were investigated in the below mentioned fresh mortar characteristics to determine the arithmetic mean values.

\subsubsection{Fresh bulk density}

Fresh bulk density of the mortar mixes were determined by evaluating the mass and volume of fresh mortar immediately after the casting as per BS EN 1015-6 [26].

\subsubsection{Consistency}

Consistency of the mortars was determined using flow table method as specified in BS EN 1015-3 [27]. Mortar was placed on a flow table in the truncated mould in two layers. Thereafter the flow table was mechanically raised by $10 \mathrm{~mm}$ and dropped at a rate of once per second for about $15 \mathrm{~s}$. Thereafter diameter of the mortar flow was measured in orthogonal directions to determine the consistency of mixes.

\subsubsection{Air content}

Further the air content was measured as per BS EN 1015-7 [28] by pouring and tamping the mortar in air entrainment meter and applying an air pressure that forced the application of water into the mortar and relocating the air within the pores. The reduced amount of water was recorded as the volume of air in the mortar to nearest $0.1 \%$.

\subsection{Tests for hardened mortar properties}

The hardened mortar properties were investigated through measuring dry density, porosity, water absorption, sorptivity, compressive strength, flexural strength, tensile strength and shrinkage. The methodologies followed to determine these hardened mortar properties are briefly explained below. Six sets of samples were tested in the below mentioned hardened mortar tests to determine the arithmetic mean values.

\subsubsection{Dry density and porosity}

The dry density of hardened mortar was determined as per BS EN 1015-10 [29] and the calculation was made according to the Eq. (1) given below. Mortar cubes of $50 \mathrm{~mm}$ were casted and air cured for 28 days at room temperature at $28{ }^{\circ} \mathrm{C} \pm 2{ }^{\circ} \mathrm{C}$ and relative humidity around $85 \%$. While there are many methods of curing mortars, the air curing was selected to represent the realistic condition in this research (Investigating the influence of other curing methods are out of the scope of this research). Initially the immersed masses of the mortar specimens were measured; thereafter surface saturated masses (SSD) of the specimen were determined. Finally the specimens were kept in the oven for nearly $24 \mathrm{~h}$ at $60^{\circ} \mathrm{C}$ to obtain the dry masses of the specimens to determine the dry densities. Additionally, the differences in mass between the surface saturated and dry conditions of hardened mortars were used to calculate the apparent porosity as a percentage of the bulk specimen volume as according to Eq. (2). 
Dry Density $=\frac{\text { Dry Mass }}{\text { SSD Mass }- \text { Immersed Mass }} \times 1000$

Apparent Porosity $=\frac{\text { SSD Mass }- \text { Dry Mass }}{S S D \text { Mass }- \text { Immersed Mass }}$

\subsubsection{Water absorption and sorptivity}

The total water absorption of the mortar mixes were determined as according to the BS EN 1015-18 [30]. Mortar cubes of $50 \mathrm{~mm}$ were casted and air cured for 28 days. After 28 days of casting the cubes were dried in oven at $60^{\circ} \mathrm{C}$ for $24 \mathrm{~h}$ and then were partially immersed in water for $24 \mathrm{~h}$. The change in mass percentage (from oven dry mass to immersed mass) of the mortar was considered as the amount of water absorption.

The sorptivity of cementitious material defines the rate of absorbing and transmitting water by capillary action. The method proposed by Reda Taha et al. [31] was used to determine the sorptivity of mortar mixes in this research. Rectangular mortar prisms of $40 \mathrm{~mm} \times 40 \mathrm{~mm} \times 160 \mathrm{~mm}$ were casted and air cured for 28 days. After 28 days, samples were oven dried for $24 \mathrm{~h}$ and the constant dry mass was recorded. Subsequently the longer edges of prisms were wrapped with insulation tapes for waterproofing and specimens were immersed partially on unwrapped side to a depth of $5 \mathrm{~mm}$ in water. Thereafter mass readings were taken at regular intervals of $(t=5,10,15,30,45$ and $60 \mathrm{~min})$ and kept them back in water for the selected time period. Finally, the sorptivity was determined as per Eq. (3):

$i=S \sqrt{ } t$

where $S$ is the sorptivity, $i$ is the water absorption per unit area of inflow surface and $t$ is the elapsed time.

\subsubsection{Compressive strength}

ASTM C109/C109 M [32] was followed to determine the compressive strength of mortars. $50 \mathrm{~mm}$ cubes moulds were used to cast the test samples as shown in Fig. 3(a). The samples were kept in the moulds for $24 \mathrm{~h}$ prior to demoulding with upper surface exposed to air. Thereafter the specimens were removed from the moulds and air cured to up to 28 days prior to testing. The compression test was carried out on a $50 \mathrm{kN}$ capacity loading machine as shown in Fig. 4a with a displacement loading rate of $0.5 \mathrm{~mm} / \mathrm{min}$. Plywood pieces of $3 \mathrm{~mm}$ were inserted between sample and loading platens to avoid any platen restrain during the testing.

\subsubsection{Flexural and tensile strengths}

The flexural strength of mortar was determined as per the method outlined in BS EN 1015-11 [33]. Rectangular mortar prisms of $40 \mathrm{~mm} \times 40 \mathrm{~mm} \times 160 \mathrm{~mm}$ were casted and tested under three point bending as shown in Fig. $4 \mathrm{~b}$. Further the tensile strength of the mortar mixes was
Fig. 3 Mortar casting methods $\mathbf{a}$ non-absorbent moulds and $\mathbf{b}$ absorbent moulds
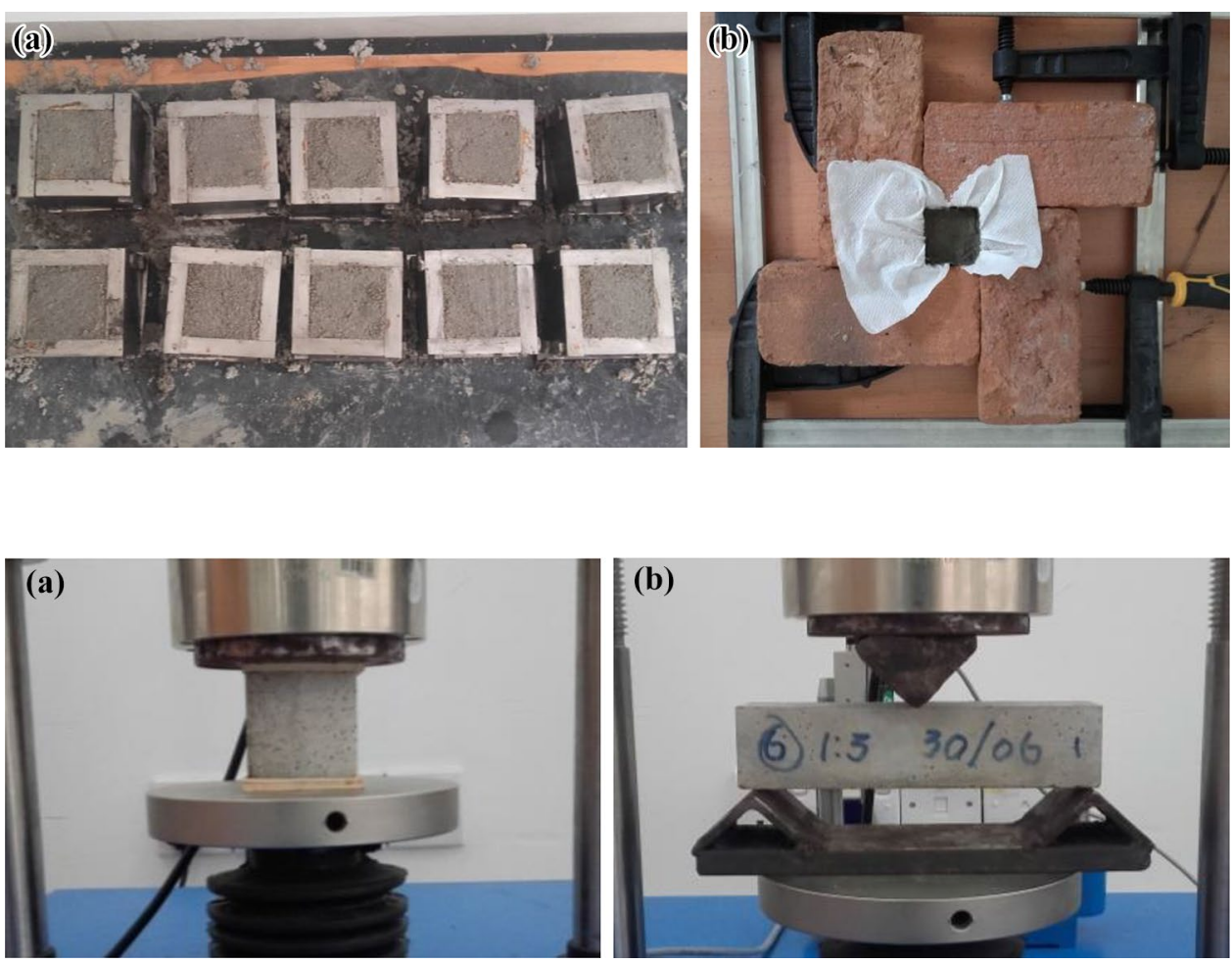

SN Applied Sciences A SPRINGER NATURE journal
Fig. 4 Testing of hardened properties of mortars a compression and $\mathbf{b}$ flexural tests 
determined from the flexural strength values of the mortars using the Eq. (4) suggested by Model Code 90, where the $h$ and $f_{\text {flex }}$ are height and flexural strength of the specimen respectively.

$f_{t}=\frac{0.06 h^{0.7}}{1+0.06 h^{0.7}} f_{\text {flex }}$

\subsubsection{Shrinkage}

Further the shrinkage test on mortar mixes were carried out according to specifications of ASTM C59609 [34]. The mortar mixes were initially casted in $40 \mathrm{~mm} \times 40 \mathrm{~mm} \times 160 \mathrm{~mm}$ rectangular prism moulds and moist cured in for $48 \mathrm{~h}$. Thereafter the specimens were demoulded and kept in lime saturated water for additional $24 \mathrm{~h}$. At the age of $72 \mathrm{~h} \pm 30 \mathrm{~min}$ the samples were removed from lime saturated water and blotted with a damp cloth. Thereafter the initial length reading for each specimen was taken. Then the specimens were air cured for 25 days at room temperature at $28^{\circ} \mathrm{C} \pm 2{ }^{\circ} \mathrm{C}$ and relative humidity around $85 \%$. The length change percentage of each specimen at different ages of air curing (4th, 11th, 18th and 25th days) was determined by subtracting from the initial reading and reported as the linear shrinkage of the mortar mixes.

\subsubsection{Absorbent condition casting}

Moreover, masonry mortars are laid on the units to construct the walls. Therefore mortar would gradually loose water due to hydration and absorption of masonry units. Thus the hardened mortar characteristic of absorbent condition is different to non-absorbent casting practices stated in many testing standards. Therefore in this research the samples were casted in clay brick barrier moulds as shown in the Fig. $3 \mathrm{~b}$ to investigate the hardened absorbent mould characteristics of mortars. Since the intention of this examination was to compare the absorbent and non-absorbent casting condition of mortar characteristics, the brick was purposely selected to represent the poorest water absorbent characteristics in the market. The water absorption and sorptivity of the selected clay brick were $12.5 \%$ and $0.0021 \mathrm{~g} / \mathrm{mm}^{2} / \mathrm{min}^{0.5}$. Paper serviettes were placed between bricks and mortar to avoid the bond development and allow the water suction from the mortar into bricks. Subsequently testing of hardened properties of mortars were carried out similarly to previous methods.

\section{Results and discussion}

\subsection{Fresh mortar properties}

The fresh mortar properties of the mortars are presented in Table 4. The coefficients of variations are given in parentheses. The fresh bulk density varied between $2058 \mathrm{~kg} / \mathrm{m}^{3}$ to $1693 \mathrm{~kg} / \mathrm{m}^{3}$ for the mortar mixes investigated. The reduction of $\mathrm{w} / \mathrm{c}$ ratio has slightly increased the fresh bulk density of some of the mixes as the volume occupied by water was replaced by fine aggregates. Further it could be observed that the incorporation of lime in the mortar decreases the fresh density of the mix. This could be due the addition of finer and lighter lime particles in lime-cement mortars.

The consistency of mortar is essential as it influences the workmanship. It is apparent that the reduction in $\mathrm{w} / \mathrm{c}$ ratio from 1.0 to 0.8 reduced the consistency of mortars by nearly $10 \%$ across all mortar mixes. It could be noted that the 1:3 mortar mix depicted higher workability than other mortars. It is because of the higher amount of water added to maintain the designated $\mathrm{w} / \mathrm{c}$ ratio in the mortar. It is also seen that the lime-cement mortars are less workable than the cement mortars. It could be due to the addition of lime that increased the fine content of the mixes and thereby reduced the consistency. Similar observations were reported previously by Haach et al. [9] and Bauer et al. [35].

The air content varied in between $4.8 \%$ and $12.2 \%$ in the mortar mixes investigated, which is to be expected without addition of any air entrainers. As the cement proportion reduces in the mortar, the air content increased in the mortar mixes. The reduction of $\mathrm{w} / \mathrm{c}$ ratio also slightly decreased the air-content of some of the mortar mixes. This could be due to the reduction of water and increase of solid content, reduced the tendency of entrapped air in the mortar. Similar observations were made on concrete by Felekoglu et al. [36].

Table 4 Fresh Mortar Properties

\begin{tabular}{lllr}
\hline Mortar mix & Flow value/(mm) & $\begin{array}{l}\text { Fresh bulk } \\
\text { density/(kg/ } \\
\left.\mathrm{m}^{3}\right)\end{array}$ & Air content/(\%) \\
\hline A1 & $203(6.13)$ & $2058(0.73)$ & $6(0.4)$ \\
A2 & $137(2.17)$ & $1899(2.09)$ & $10(0.7)$ \\
A3 & $149(0.2)$ & $1704(1.57)$ & $10.5(0.8)$ \\
A4 & $147(0.5)$ & $1994(0.15)$ & $11(0.9)$ \\
A5 & $135(0.2)$ & $1863(0.81)$ & $12.2(1.1)$ \\
B1 & $180(3.4)$ & $2073(1.8)$ & $4.80(0.6)$ \\
B2 & $120(0.1)$ & $2041(0.39)$ & $10.0(1.2)$ \\
B3 & $147(0.3)$ & $1693(1.11)$ & $10.5(0.8)$ \\
B4 & $116(0.2)$ & $2003(1.08)$ & $9.5(0.6)$ \\
B5 & $123(0.3)$ & $1797(0.60)$ & $11(1.1)$ \\
\hline
\end{tabular}




\subsection{Hardened mortar properties}

\subsubsection{Dry density and porosity results}

The hardened mortar properties of non-absorbent mould casting are given in Table 5. The coefficients of variations are given in parentheses. The dry density of mortar mixes varied between $1706 \mathrm{~kg} / \mathrm{m}^{3}$ and $2022 \mathrm{~kg} / \mathrm{m}^{3}$. The dry densities of the trialled mortars reduced nearly by $5 \%$ than their fresh bulk densities. However similar trend could be observed between dry and fresh bulk densities of mortars. The porosities of the tested mortar mixes varied between $16.7 \%$ and $24.3 \%$. The porosity of the mortars reduced as the $\mathrm{w} / \mathrm{c}$ ratio is decreased. Also incorporation of lime in the mortars has shown to reduce the porosity of mortars. This could be due the higher finer content of lime. The calculated porosity of the mortars were highest for $\mathrm{A} 3$ and $\mathrm{B} 3$ $(1: 8)$ mixes. This is because of higher sand content in the mixes. The A2 and B2 mortar mixes (1:5) showed the lowest porosities among the mortar mixes trialled.

\subsubsection{Water absorption and sorptivity results}

The water absorption of the mortar mixes varied from 7.47 to $12.28 \%$. The A3 and B3 mortar mixes (1:8) have shown the highest water absorption. Further A5 and B5 (1:1:6) mortar mixes have depicted lowest water absorption capacity. It can be noted that the higher the porosity in the mortar mixes the higher the water absorption. It also can be seen that the lime-cement mortars have shown slightly lesser water absorption characteristics than cement mortars. Up to now there is no precise specification limit for water absorption of masonry mortar. However ASTM C55-17 [37] specifies that the normal and medium weight masonry units should have maximum water absorption of $8 \%$ and $11.3 \%$ respectively. Since masonry is an assembly of unit and mortars, the same limit could be considered for mortar mixes. Therefore it can be said except $A 3$ and B3 mortar mixes (1:8), all other mortar mixes comply with the specification. The sorptivity of the mortar mixes varies similar to water absorption trend. However the A1 and B1 mortar mixes show relatively higher sorptivity than other mixes. It could be due to the higher finer pores in the $A 1$ and B1 mortars than other mixes that lead to higher capillary suction.

\subsubsection{Compressive strength results}

The $w / c$ ratio greatly influences the compressive strength of mortars. The increase of $\mathrm{w} / \mathrm{c}$ ratio clearly reduced the compressive strength of mortar mixes. The excess water in the mixes subsequently created voids in the hardened mortar, which can be cross referred between density and porosity values of corresponding mixes that lead to the reduction of strength. Also it can be noted that the introduction of lime in cement mortar mixes slightly reduces the compressive strength.

Nevertheless mortar strengths are classified in BS EN 1996-1-1 [1] as according to their compressive strength expressed as the letter $M$ followed by the compressive strength in MPa. Therefore the tested mortar mixes $A 1$, $A 2, A 3, A 4$ and $A 5$ (and $B$ series) are correspond to $M 12$, M4, M2, M6 and M4 mortar strength classes respectively as according to the national annex of BS NA EN 1996-1-1 [1]. Therefore except the $A 1$ and $A 3$ mortar mixes; all other mortar mixes complied with BS NA EN 1996-1-1 [1]. Consequently as the $\mathrm{w} / \mathrm{c}$ ratio influences the strength of the mortar, it would be prudent to include the limiting values of $\mathrm{w} / \mathrm{c}$ for varies mortar mixes in standards.

Table 5 Hardened Mortar Properties (Non-Absorbent mould specimens)

\begin{tabular}{llllllll}
\hline Mortar mix & $\begin{array}{l}\text { Dry density } \\
\left(\mathrm{kg} / \mathrm{m}^{3}\right)\end{array}$ & Porosity (\%) & Water absorption (\%) & $\begin{array}{l}\text { Sorptivity } \\
\left(\mathrm{g} / \mathrm{mm}^{2} / \mathrm{min}^{0.5}\right)\end{array}$ & $\begin{array}{l}\text { Compressive } \\
\text { strength (MPa) }\end{array}$ & $\begin{array}{l}\text { Flexural } \\
\text { strength } \\
(\mathrm{MPa})\end{array}$ & $\begin{array}{l}\text { Tensile strength (MPa) } \\
\text { A1 }\end{array}$ \\
\hline $1929(0.5)$ & $17.6(0.1)$ & $8.71(0.9)$ & $0.0012(8.1)$ & $8.46(2.7)$ & $1.46(7.7)$ & $0.64(7.7)$ \\
A2 & $1847(0.4)$ & $16.7(0.3)$ & $8.52(1.6)$ & $0.0008(1.5)$ & $5.98(4.7)$ & $1.14(12.4)$ & $0.50(12.4)$ \\
A3 & $1706(0.2)$ & $24.3(0.7)$ & $12.28(2.8)$ & $0.0011(7.4)$ & $1.60(4.8)$ & $0.43(12.6)$ & $0.19(12.5)$ \\
A4 & $1924(0.3)$ & $17.7(0.8)$ & $8.76(0.4)$ & $0.0008(6.2)$ & $8.40(5.2)$ & $1.00(10.5)$ & $0.44(10.5)$ \\
A5 & $1851(0.4)$ & $17.6(0.3)$ & $8.33(1.2)$ & $0.0009(7.4)$ & $5.76(4.7)$ & $0.60(6.8)$ & $0.27(6.8)$ \\
B1 & $2022(0.1)$ & $17.1(0.1)$ & $7.74(0.2)$ & $0.0009(7.1)$ & $10.23(1.5)$ & $1.62(10.3)$ & $0.72(10.2)$ \\
B2 & $1974(0.1)$ & $16.9(0.9)$ & $7.55(2.8)$ & $0.0005(10.1)$ & $8.65(3.2)$ & $1.20(6.3)$ & $0.53(6.3)$ \\
B3 & $1771(0.5)$ & $22.2(0.2)$ & $11.32(1.3)$ & $0.0010(1.6)$ & $3.16(0.1)$ & $0.49(11.3)$ & $0.22(11.3)$ \\
B4 & $1954(0.2)$ & $17.1(0.9)$ & $7.86(0.3)$ & $0.0008(8.8)$ & $9.20(2.0)$ & $1.23(4.5)$ & $0.54(4.5)$ \\
B5 & $1837(0.3)$ & $19.4(0.5)$ & $10.47(3.6)$ & $0.0011(4.2)$ & $7.07(5.9)$ & $0.68(11.3)$ & $0.21(11.3)$ \\
\hline
\end{tabular}




\subsubsection{Flexural and tensile strength results}

The flexural and tensile strength of the mortars are indirectly influence the performance of masonry under lateral loading condition. Therefore measurement of flexural and tensile strengths would be useful for appropriate selection of mortar for masonry application. As of the compressive strength, flexural strength also increases with the reduction of $w / c$ ratio and similar pattern can be observed among the mortar mixes. The flexural strength ranges from 0.6 MPa to $1.62 \mathrm{MPa}$. The calculated tensile strength of the mortar mixes are also given in Table 5. The lowest tensile strength of $0.19 \mathrm{MPa}$ was reported for A3 mortar $\operatorname{mix}(1: 8)$.

\subsubsection{Absorbent condition results}

The hardened mortar properties of absorbent mould specimens are given in Table 6. Only fractional changes (nearly $5 \%$ reduction) in the dry density between absorbent and non-absorbent moulds can be noted. Therefore it shows the consistency of mixing and casting the specimens in both testing conditions. It could be generally observed that the porosity, water absorption and sorptivity of the mortars casted in absorbent moulds increased nearly between $10 \%$ to $15 \%$. The loss of required water due to masonry unit suction and inability of complete curing of mortars in the absorbent moulds have inhibited the proper hydration process in the mortar, that lead to slightly higher porosity and thereby higher water absorption and sorptivity values. However despite of mortars been casted in the absorbent moulds the water absorption values of all the mortars (except $\mathrm{A} 3$ and $\mathrm{B} 3$ ) remain within the standard range $(8 \%-11.3 \%)$ as discussed before.

Further the compressive, flexural and tensile strengths of absorbent mould mortars are lesser than the corresponding non-absorbent mould mortars. The lowest and highest compressive, flexural and tensile strengths were reported for $\mathrm{A} 3$ and $\mathrm{B} 1$ mortar mixes respectively as non-absorbent mould mortars. Similar to the non-absorbent mould results, the $A 1$ and $A 3$ mortar mixes did not comply the BS EN 1996-1-1 [1] compressive strength limits. However the compressive strengths of other mortar mixes are higher than the BS EN 1996-1-1 [1]. Therefore it could be pulsated that the non-absorbent strength testing of mortars can still be followed as the standard values are conservatively specified.

Further compressive strength of the cementitious materials can be correlated to the porosity. However the research studies on this relationship of commonly used masonry mortar compressive strength and porosity is not available. Therefore from the limited experimental data gathered (Non-Absorbent and Absorbent) relationship between masonry mortar compressive strength and porosity is proposed and shown in Fig. 5. A power function was found to be best fit for the data with coefficient of correlation 0.72 . While more data could be desirable

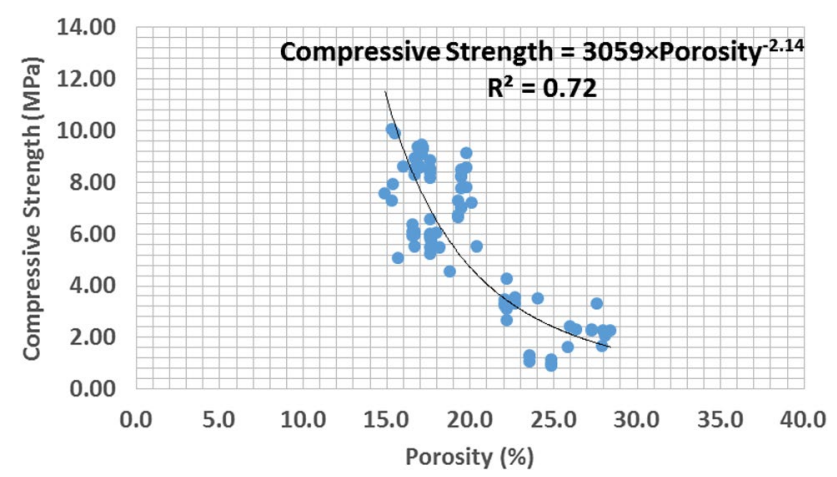

Fig. 5 Relationship between compressive strength and porosity of mortars

Table 6 Hardened mortar properties (absorbent mould specimens)

\begin{tabular}{llllllll}
\hline Mortar mix & $\begin{array}{l}\text { Dry density } \\
\left(\mathrm{kg} / \mathrm{m}^{3}\right)\end{array}$ & Porosity (\%) & Water absorption (\%) & $\begin{array}{l}\text { Sorptivity } \\
\left(\mathrm{g} / \mathrm{mm}^{2} / \mathrm{min}^{0.5}\right)\end{array}$ & $\begin{array}{l}\text { Compressive } \\
\text { strength (MPa) }\end{array}$ & $\begin{array}{l}\text { Flexural } \\
\text { strength } \\
(\mathrm{MPa})\end{array}$ & $\begin{array}{l}\text { Tensile strength (MPa) } \\
\text { A1 }\end{array}$ \\
\hline $1886(3.4)$ & $19.8(1.1)$ & $9.78(3.5)$ & $0.0014(9.8)$ & $6.74(8.2)$ & $1.03(16.5)$ & $0.46(16.5)$ \\
A2 & $1812(5.6)$ & $19.1(2.3)$ & $10.21(1.9)$ & $0.0010(8.8)$ & $4.95(12.7)$ & $0.54(21.0)$ & $0.24(21.0)$ \\
A3 & $1695(5.1)$ & $27.3(3.6)$ & $15.5(7.2)$ & $0.0013(13.6)$ & $1.24(6.2)$ & $0.25(3.0)$ & $0.11(3.0)$ \\
A4 & $1895(6.0)$ & $21.7(3.1)$ & $10.66(4.0)$ & $0.0011(11.8)$ & $5.35(11.6)$ & $0.37(18.8)$ & $0.16(18.8)$ \\
A5 & $1790(2.5)$ & $19.8(3.8)$ & $10.39(5.1)$ & $0.0012(4.0)$ & $4.44(3.1)$ & $0.24(10.2)$ & $0.11(10.2)$ \\
B1 & $1999(6.0)$ & $18.3(1.6)$ & $7.94(1.0)$ & $0.0012(18.2)$ & $9.17(12.4)$ & $1.16(8.4)$ & $0.51(8.4)$ \\
B2 & $1859(3.6)$ & $18.0(5.1)$ & $11.18(7.3)$ & $0.0008(32.4)$ & $5.65(21.4)$ & $0.91(6.5)$ & $0.40(6.5)$ \\
B3 & $1743(3.6)$ & $24.3(3.2)$ & $15.8(3.1)$ & $0.0011(5.4)$ & $2.26(1.9)$ & $0.70(13.0)$ & $0.31(13.2)$ \\
B4 & $1896(8.4)$ & $19.6(2.4)$ & $8.92(1.7)$ & $0.0010(0.0)$ & $6.99(16.8)$ & $1.24(10.2)$ & $1.24(10.2)$ \\
B5 & $1842(7.9)$ & $19.2(3.8)$ & $8.33(4.4)$ & $0.0011(11.0)$ & $5.86(16.4)$ & $0.68(13.2)$ & $0.30(13.2)$ \\
\hline
\end{tabular}


to confirm the trend, the power function relationship between compressive strength and porosity in masonry mortar is similar to other cementitious materials.

\subsubsection{Shrinkage results}

The measured shrinkage characteristics of the nonabsorbent mortars are presented in Fig. 6a, b. It can be seen that the $A 1$ and $B 1$ mortars have shown higher shrinkage tendency than other mortar mixes. Therefore increase of cement content increases the shrinkage tendency in the mortars. Further the addition of lime does not significantly influence the shrinkage characteristics of mortars. Moreover reducing the $\mathrm{w} / \mathrm{c}$ ratio has reduced the shrinkage of mortars. The shrinkage of $B$ series mortars depicts to become unchanged after 21 days of measurement. Therefore it could be said the shrinkage can be controlled by reducing $\mathrm{w} / \mathrm{c}$ ratio in cement and cement-lime mortars, which is important to reduce the creep effect on masonry.

Further the shrinkage characteristics of absorbent mould specimens are shown in Fig. $6 \mathrm{c}$, d. It can be obviously seen that the shrinkage of absorbent mould mortars are nearly five times higher than of the nonabsorbent mould mortars. The rapid loss of water due to masonry unit suction in the early stage of casting could have triggered higher shrinkage in the mortars. However
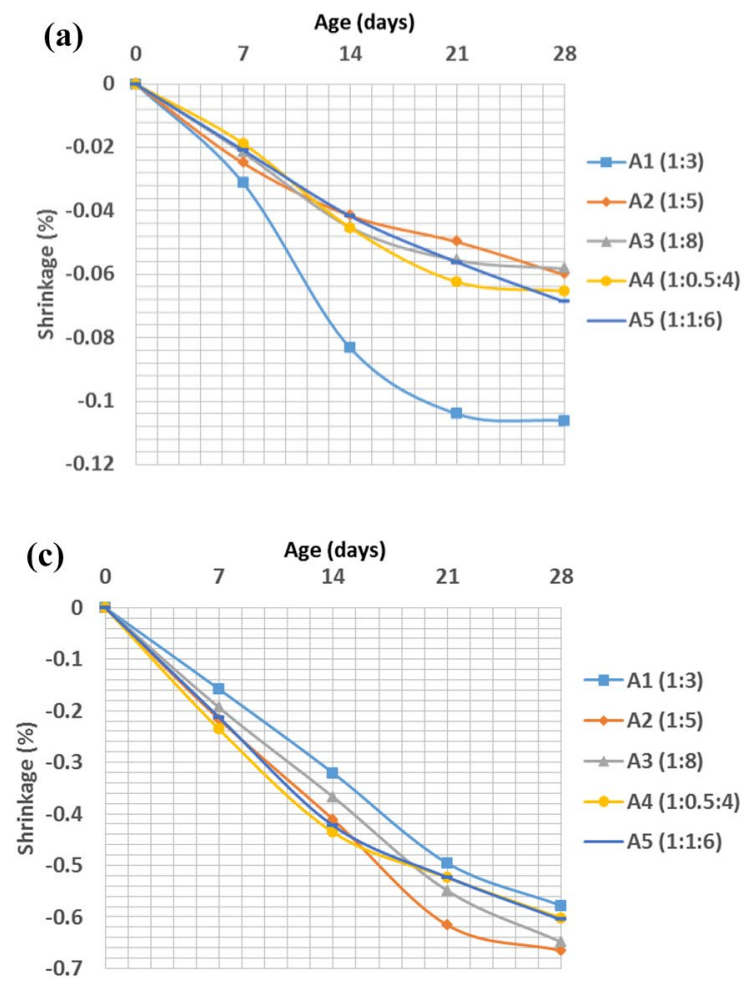

as the $\mathrm{w} / \mathrm{c}$ ratio decreases the shrinkage of the mortar reduces as the non-absorbent specimens. Further no clear distinction could be made on the shrinkage characteristics of the absorbent mould mortars. Nevertheless the shrinkage of $B$ series mortar mixes have shown to become constant nearly after 21 days of casting. Hence is conformed that the shrinkage can be limited by controlling the $w / c$ ratio in the masonry mortars.

\section{Detail specification of masonry mortars}

As stated before the detail specification is necessary to reduce the inconsistency in preparing mortar mix for masonry application. Therefore authors identified following four parameters are to be provided to prepare the masonry mortar mix for each mortar designation (1) consistency limits (2) $\mathrm{w} / \mathrm{c}$ ratio threshold (3) aggregate gradation and (4) Target compressive strength. Out of these four parameters, the aggregate gradation that required for masonry mortar is already recommended in ASTM C144-17 [20]. The specification of the fine aggregate should be such that the maximum size of the sand should be $2.36 \mathrm{~mm}$, and the fineness modulus should be within 2.2-2.6. As there are many parameters (e.g. w/c ratio, practical size, mixing methods, and climatic conditions) influencing the consistency of masonry mortar, setting of a constant value
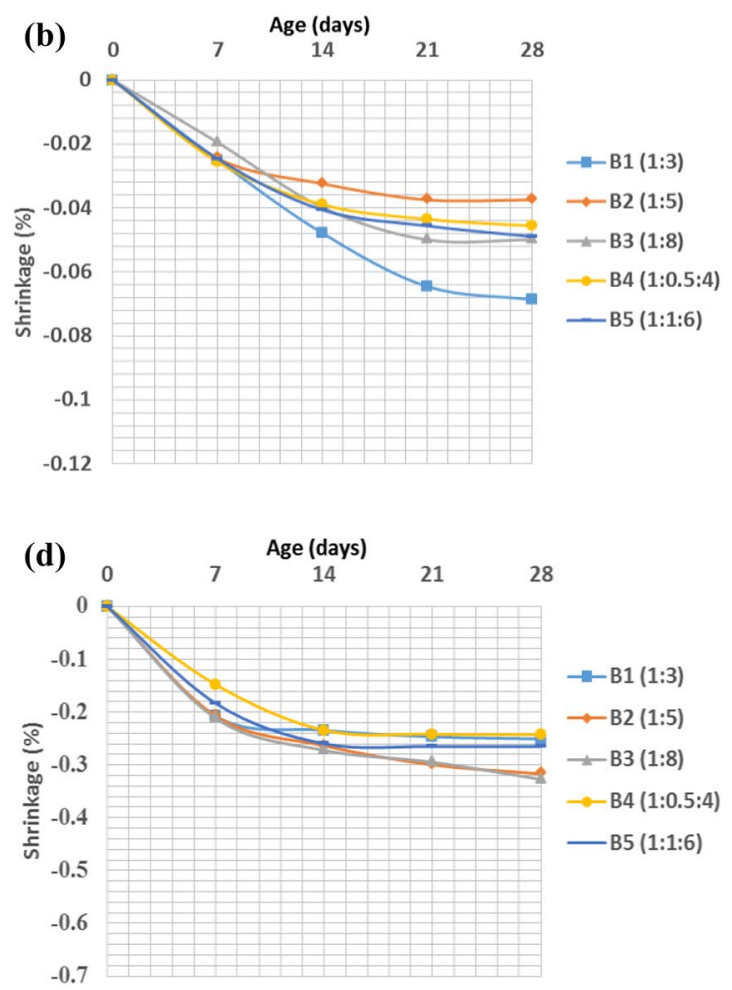

Fig. 6 Shrinkage measurement of mortar mixes 
for consistency of mortar is impractical in any case. However it can be said that the masonry mortar should have consistency (flow value) of $120 \mathrm{~mm}( \pm 10 \mathrm{~mm})$ to have sufficient workability to place on the masonry units. Therefore this consistency range was considered as the reference to determine the suitable $\mathrm{w} / \mathrm{c}$ ratio and target compressive strength in this section.

Thus further investigations were carried out on the selected mortar types to determine the suitable $\mathrm{w} / \mathrm{c}$ ratio and corresponding target compressive strength. For that only consistency and compressive strengths were measured on the selected masonry mortar types with different $\mathrm{w} / \mathrm{c}$ ratios. Consequently $\mathrm{w} / \mathrm{c}$ ratios of $0.75,0.7,0.65$ and 0.6 were trialled on the selected mortars (already $\mathrm{w} / \mathrm{c}$ ratios of 1.0 and 0.8 trialled in phase two of the research). The compressive strengths were determined through absorbent and non-absorbent mould conditions to further verify the reliability of target strength for these additional $\mathrm{w} / \mathrm{c}$ ratio trials. The same testing procedures that explained in Sects. 2.3.2, 2.4.3 and 2.4.6 were followed to determine the consistency and compressive strengths respectively.

Table 7 presents the consistency and compressive strength values of the trials considered. The designation of the selected mortar as per BS NA EN 1996-1-1 [1] are given in the Table 7. The consistency values are mean of three samples (measured in two perpendicular directions per sample) and the compressive strength values are mean of six samples in the Table 7. The coefficients of variance are given in the parentheses. It can be seen that the reduction of $\mathrm{w} / \mathrm{c}$ ratio reduces the consistency of all mortars. Further the compressive strengths of the mortars increase with the reduction of $\mathrm{w} / \mathrm{c}$ ratio. Obviously the non-absorbent mould compressive strength of the mortar is higher than the corresponding absorbent mould specimens.

The suitable $\mathrm{w} / \mathrm{c}$ ratio that corresponded to the specified consistency limit (i.e. $120 \mathrm{~mm} \pm 10 \mathrm{~mm}$ ) and compressive strength can be identified from the Table 7 for the detail specification. Therefore the detail specifications of the selected mortars are recommended in the Table 8 for masonry mortar mix design. A range of $\mathrm{w} / \mathrm{c}$ ratio is proposed for each mortar mix, as the corresponding consistency is given in a range. Further the target compressive strengths are achieved consistently (both in absorbent and non-absorbent conditions) for the selected mortars with proposed $\mathrm{w} / \mathrm{c}$ ratios and consistency limit. It is be emphasised that the proposed $\mathrm{w} / \mathrm{c}$ ratio range each mortar designation is conservative as they have given the lowest stipulated strength (lower bound) and within the consistency limit.

Therefore the proposed mortar specification can be useful for preparing the mortar mix for masonry application. Once the fine aggregate to be used in the mortar

Table 7 Consistency and compressive strengths of mortars

\begin{tabular}{|c|c|c|c|c|c|c|c|}
\hline \multirow{2}{*}{$\begin{array}{l}\text { Mortar class as per BS NA } \\
\text { EN 1996-1-1:2005 }\end{array}$} & \multicolumn{3}{|c|}{ Mortar designation } & \multirow[t]{2}{*}{ w/c ratio } & \multirow[t]{2}{*}{ Consistency/(mm) } & \multicolumn{2}{|c|}{ Compressive strength/(MPa) } \\
\hline & Cement & Lime & Sand & & & $\begin{array}{l}\text { Non-absorbent } \\
\text { mould }\end{array}$ & Absorbent mould \\
\hline \multirow[t]{4}{*}{ M12 } & 1 & 0 & 3 & 0.75 & $161(2.7)$ & $10.5(5.6)$ & $9.55(7.7)$ \\
\hline & & & & 0.7 & $151(1.8)$ & $11.4(6.4)$ & $10.2(10.4)$ \\
\hline & & & & 0.65 & $139(1.3)$ & $12.1(3.1)$ & $10.8(7.2)$ \\
\hline & & & & 0.6 & $124(2.2)$ & 13.7 (5.4) & $12.5(9.6)$ \\
\hline \multirow[t]{4}{*}{ M4 } & 1 & 0 & 5 & 0.75 & $114(3.2)$ & $9.3(5.8)$ & $5.9(9.2)$ \\
\hline & & & & 0.7 & $109(1.8)$ & $9.9(7.8)$ & $6.1(8.0)$ \\
\hline & & & & 0.65 & $103(2.1)$ & $10.0(4.8)$ & $6.3(8.3)$ \\
\hline & & & & 0.6 & $97(2.6)$ & $10.3(4.2)$ & $6.4(8.6)$ \\
\hline \multirow[t]{4}{*}{ M2 } & 1 & 0 & 8 & 0.75 & $138(1.9)$ & $2.6(13.5)$ & $2.1(9.8)$ \\
\hline & & & & 0.7 & $130(2.6)$ & $3.2(8.8)$ & $2.8(8.8)$ \\
\hline & & & & 0.65 & $128(3.4)$ & $4.4(9.4)$ & $2.9(10.8)$ \\
\hline & & & & 0.6 & $125(1.7)$ & $5.3(6.4)$ & $3.0(17.8)$ \\
\hline \multirow[t]{4}{*}{ M6 } & 1 & 0.5 & 4 & 0.75 & $111(1.8)$ & $9.3(6.7)$ & $7.6(5.0)$ \\
\hline & & & & 0.7 & $106(3.1)$ & $9.6(5.1)$ & $8.0(7.6)$ \\
\hline & & & & 0.65 & $98(2.9)$ & $9.8(4.4)$ & $8.5(7.7)$ \\
\hline & & & & 0.6 & $86(2.2)$ & $10.4(5.5)$ & $8.9(8.4)$ \\
\hline \multirow[t]{4}{*}{ M4 } & 1 & 1 & 6 & 0.75 & $118(1.8)$ & $6.4(5.2)$ & $6.3(12.4)$ \\
\hline & & & & 0.7 & $114(1.5)$ & $7.6(4.9)$ & $6.8(5.1)$ \\
\hline & & & & 0.65 & $108(1.5)$ & $8.9(8.1)$ & $7.2(11.1)$ \\
\hline & & & & 0.6 & $103(1.9)$ & $9.8(9.0)$ & $7.4(6.1)$ \\
\hline
\end{tabular}


Table 8 Proposed masonry mortar specification

\begin{tabular}{|c|c|c|c|c|c|c|}
\hline \multicolumn{3}{|c|}{ Mortar designation } & \multirow{2}{*}{$\begin{array}{l}\text { Mortar class as per BS NA } \\
\text { EN 1996-1-1:2005 }\end{array}$} & \multirow[t]{2}{*}{ Consistency/(mm) } & \multirow[t]{2}{*}{ Suitable w/c ratio } & \multirow{2}{*}{$\begin{array}{l}\text { Target compres- } \\
\text { sive strength/ } \\
\text { (MPa) }\end{array}$} \\
\hline Cement & Lime & Sand & & & & \\
\hline 1 & 0 & 3 & M12 & $120 \mathrm{~mm} \pm 10 \mathrm{~mm}$ & $0.60-0.65$ & 12 \\
\hline 1 & 0 & 5 & M4 & & $0.75-0.80$ & 4 \\
\hline 1 & 0 & 8 & M2 & & $0.60-0.65$ & 2 \\
\hline 1 & 0.5 & 4 & M6 & & $0.75-0.80$ & 6 \\
\hline 1 & 1 & 6 & M4 & & $0.7-0.8$ & 4 \\
\hline
\end{tabular}

mix ensured that it is in the specified gradation range, the mortar mix can be prepared as per the designated mortar class with reference to Table 8 for masonry construction.

\section{Conclusion}

The characteristics of masonry mortars are different to general purpose mortars. It is commonly observed masonry mortar mix is merely stated as volume proportions without any additional details of required mix design parameters. Subsequently no mix design procedure is followed in masonry mortar mix preparation. This lack of detail specification leads to inconsistency in mortar mix preparation and properties. Therefore objective of this research was to characterise and determine the suitable limits of consistency and w/c ratio for commonly used masonry mortars. For that purpose five different cement and cement-lime mortar proportions were selected experimentally tested to determine the fresh and hardened properties. Initially two $\mathrm{w} / \mathrm{c}$ ratios ( 1.0 and 0.8 ) were chosen to characterise the fresh and hardened mortar properties in this research. Thereafter additional four $(0.75,0.7$, 0.65 , and 0.6 ) were selected to decide the suitable limits of consistency and $\mathrm{w} / \mathrm{c}$ ratio for commonly used masonry mortars. From the experimental results, following conclusions can be drawn:

- Consistency of mortar reduces with the reduction of $\mathrm{w} / \mathrm{c}$ ratio and the introduction of lime does not significantly influence the workability. The amounts of water absorption of the trialled mortars are in compliance with the limits of masonry units.

- The hardened properties of mortars deteriorate in the absorbent mould condition. However the water absorption and strength properties of mortars are within the standard limits in the absorbent mould condition.

- The shrinkage of the mortars can be controlled by limiting the $\mathrm{w} / \mathrm{c}$ ratio of the mortars. However careful assessment should be made to account the shrinkage characteristics of masonry mortars as the absorbent mould shrinkages are significantly higher than nonabsorbent mould mortars.

- Mix specifications for selected mortars are proposed in this research. The suitable consistency limits, w/c ratios and target compressive strength are included in the detail specification. The developed detail specification can be useful to prepare the masonry mortar mix in consistent with the mortar designations specified in the design practice.

Therefore this study contributes a step forward to develop a detail mix specification for masonry mortar, which is current overlooked in the masonry practice. Hence the mix specification proposed in the research study could be used as the based to prepare the mortar mixes for masonry application, like it is practiced in concrete mix design. It should be noted that the developed specification for masonry mortar are only limited to the cement class of CEM I 42.5 N as per BS EN 197-1 [23], climatic condition that the specimens were cured, mixing methods used. However the research will be extended to develop similar specifications for other possible cement types, climatic conditions and mixing methods of masonry mortar preparation.

Acknowledgements The authors thank the South Eastern University of Sri Lanka for the technical and financial support to this research project. The assistance of technical officers Mr. Jiffry and Mr. Imtiyas are gratefully acknowledged.

Funding information The research was funded by the South Eastern University of Sri Lanka under the research grant SEU/ASA/ RG/2016/01.

\section{Compliance with ethical standards}

Conflict of interest There is no conflict of interest in terms of financial and other aspects in this research. 


\section{References}

1. BS EN 1996-1-1: 2005 Eurocode 6: Design of masonry structures-Part 1-1: General rules for reinforced and unreinforced masonry structures. London: British Standards Institution

2. AS3700 (2011) Australian Standards for Masonry Structures. Standards Australia, Sydney

3. CSA (2004) Design of masonry structures. CSA S304.1-04 (R2010). Mississauga, Canada

4. CAN/CSA-A179-04 (R2014)-Mortar and Grout for Unit Masonry, CSA Mississauga, Canada

5. Masonry Standards Joint Committee (MSJC) (2011) Building code requirements for masonry structures. TMS 402/ASCE 5/ ACI 530, New York

6. ASTM C270-14a (2014) Standard Specification for Mortar for Unit Masonry, ASTM International, West Conshohocken, PA

7. De Schutter G, Poppe AM (2004) Quantification of water demand of sand in mortar. Constr Build Mater 18(7):517-521

8. Chen X, Wu S (2004) Influence of water to cement ratio and curing period on pre structure of cement mortar. Constr Build Mater 38:804-812

9. Haach VG, Vasconcelos G, Lourenco PB (2011) Influence of aggregates grading and water/cement ratio in workability and hardened properties of mortars. Constr Build Mater 25(6):2980-2987

10. Martínez I, Etxeberria M, Pavón P, Díaz N (2018) Influence of demolition waste fine particles on the properties of recycled aggregate masonry mortar. Int J Civ Eng 16(9):1213-1226

11. Silva RV, Jde Brito, Dhir RK (2016) Performance of cementitious renderings and masonry mortars containing recycled aggregates from construction and demolition wastes. Constr Build Mater 105:400-415

12. Coppola L, Coffetti D, Crotti E (2018) Plain and ultrafine fly ashes mortars for environmentally friendly construction materials. Sustainability 10:874

13. Thamboo JA, Dhanasekar M (2018) Effect of concrete block height variation to the shear bond strength of thin layer mortared masonry. Int J Mason Res Innov 3(2):174-193

14. Dhanasekar M, Thamboo JA, Nazir S (2017) On the in-plane shear response of the high bond strength concrete masonry walls. Mater Struct 50:214

15. Singh SB, Munjal P (2017) Bond strength and compressive stress-strain characteristics of brick masonry. J Build Eng 9:10-16

16. Venkatarama Reddy BV, Gupta A (2008) Influence of sand grading on the characteristics of mortars and soil-cement block masonry. Constr Build Mater 22(8):1614-1623

17. Martínez l, Etxeberria M, Pavón E, Díaz N (2013) A comparative analysis of the properties of recycled and natural aggregate in masonry mortars. Constr Build Mater 49:384-392

18. Thamboo JA, Dhanasekar M (2015) Characterisation of thin layer polymer cement mortared concrete masonry bond. Constr Build Mater 82:71-98

19. BS EN 998-2: 2016 Specification for mortar for masonry - Part 2: Masonry mortar, BSI
20. ASTM C144-17 (2017) Standard Specification for Aggregate for Masonry Mortar, ASTM International, West Conshohocken, PA

21. Brooks JJ, Abu Bakar BH (2004) Shrinkage and creep of masonry mortar. Mater Struct 37(3):177-183

22. Sollero $M$, Bolorino $H(2016)$ Investigation and diagnosis of a reinforced concrete reservoir with intense crack formation from several sources. J Build Rehabil 1:6

23. BS EN 197-1:2011 Cement. Composition, specifications and conformity criteria for common cements. BSI

24. ASTM C191-18a (2018) Standard Test Methods for Time of Setting of Hydraulic Cement by Vicat Needle, ASTM International, West Conshohocken, PA

25. Hatami L, Jamshidi M (2017) Influence of pigment content and cement type on appearance and performance of colored self-compacting mortars (C-SCMs). Int J Civ Eng 15(5):727-736

26. BS EN 1015-6:1999, Methods of test for mortar for masonry: determination of bulk density of fresh mortar. BSI

27. BS EN 1015-3:1999, Methods of test for mortar for masonry. Determination of consistence of fresh mortar (by flow table). BSI

28. BS EN 1015-7:1999, Methods of test for mortar for masonry. Determination of air content of fresh mortar. BSI

29. BS EN 1015-10:1999, Methods of test for mortar for masonry. Determination of dry bulk density of hardened mortar. BSI

30. BS EN 1015-18:2002, Methods of test for mortar for masonry. Determination of water absorption coefficient due to capillary action of hardened mortar. BSI

31. Reda Taha MM, El-Dieb AS, Shrive NG (2001) Sorptivity: a reliable measurement for surface absorption of masonry brick units. Mater Struct 34:438-445

32. ASTM C109/C109 M-16a (2016). Standard test method for compressive strength of hydraulic cement mortars (using 2-in. or [50-mm] cube specimens), USA

33. BS EN 1015-11:1999, Methods of test for mortar for masonry. Determination of flexural and compressive strength of hardened mortar, BSI

34. ASTM C596-09 (2017) Standard test method for drying shrinkage of mortar containing hydraulic cement. ASTM International, West Conshohocken

35. Bauer E, Silva EF, Sousa JGG, Salomao MCF (2015) Friction influence between particles in the behavior of flow of lime-rendering mortars. J Mater Civil Eng 27(3)

36. Felekoglu B, Türkel S, Baradan B (2007) Effect of water/cement ratio on the fresh and hardened properties of self-compacting concrete. Build Environ 42(4):1795-1802

37. ASTM C55-17, Standard Specification for Concrete Building Brick, ASTM International, West Conshohocken

Publisher's Note Springer Nature remains neutral with regard to jurisdictional claims in published maps and institutional affiliations. 